\title{
An Insight Into Ameliorating Production, Catalytic Efficiency, Thermostability and Starch Saccharification of Acid-Stable $\alpha$-Amylases From Acidophiles
}

\author{
Deepak Parashar ${ }^{1}$ and Tulasi Satyanarayana ${ }^{2 *}$ \\ ' Functional Genomic Unit, CSIR-Institute of Genomics and Integrative Biology, New Delhi, India, ${ }^{2}$ Division of Biological \\ Sciences and Engineering, Netaji Subhas Institute of Technology, New Delhi, India
}

OPEN ACCESS

Edited by:

Caixia Wan

University of Missouri, United States

Reviewed by:

Fu-Li Li,

Qingdao Institute of Bioenergy and Bioprocess Technology (CAS), China Roland Wohlgemuth, Lodz University of Technology, Poland

*Correspondence:

Tulasi Satyanarayana

tsnarayana@gmail.com

Specialty section:

This article was submitted to Process and Industrial Biotechnology,

a section of the journal

Frontiers in Bioengineering and

Biotechnology

Received: 30 December 2017

Accepted: 20 August 2018

Published: 28 September 2018

Citation:

Parashar D and Satyanarayana T

(2018) An Insight Into Ameliorating

Production, Catalytic Efficiency,

Thermostability and Starch

Saccharification of Acid-Stable

a-Amylases From Acidophiles.

Front. Bioeng. Biotechnol. 6:125.

doi: 10.3389/fbioe.2018.00125
Most of the extracellular enzymes of acidophilic bacteria and archaea are stable at acidic $\mathrm{pH}$ with a relatively high thermostability. There is, however, a dearth of information on their acid stability. Although several theories have been postulated, the adaptation of acidophilic proteins to low $\mathrm{pH}$ has not been explained convincingly. This review highlights recent developments in understanding the structure and biochemical characteristics, and production of acid-stable and calcium-independent $\alpha$-amylases by acidophilic bacteria with special reference to that of Bacillus acidicola.

Keywords: acidophiles, Bacillus acidicola, acid-stable $\alpha$-amylase, thermostability, starch saccharification

\section{INTRODUCTION}

Enzyme characteristics such as thermostability, selectivity, solvent tolerance and substrate affinity can be improved through genetic engineering based on the availability of large data on improving these characteristics (Verma and Satyanarayana, 2012; Widersten, 2014; Joshi and Satyanarayana, 2015). Alteration in $\mathrm{pH}$ stability is tedious and lacks rational approaches. However, a few reports on enhancing acid stability of $\alpha$-amylases through protein engineering are available (Liu et al., 2008a, 2012; Yang et al., 2013).

The majority of the enzymes used at commercial scale lack adequate acid stability, thus limiting their applications. For using such enzymes, adjusting $\mathrm{pH}$ to their optima is required, which makes the process tedious, expensive and time consuming. In order to overcome the problems, many industries use acid-stable enzymes from fungal sources. Since these lack adequate thermostability, the enzymes get denatured when processes are carried out at elevated process temperatures (Demirjian et al., 2001; Elleuche et al., 2014). In order to overcome these problems, microbes that are capable of tolerating harsh conditions could be exploited for naturally tailored enzymes that are superior to their neutrophililic counterparts for utility under harsh bioprocess conditions (Hough and Danson, 1999; Eichler, 2001; Sharma et al., 2012; Raddadi et al., 2015). It has generally been observed that the enzymes from acidophilic microbes function under their optimal growth conditions (Ferrer et al., 2007), thus find several commercial applications. Furthermore, the study of these enzymes might also enable us to understand the underlying mechanisms to make them functional in extreme acidic conditions (Demirjian et al., 2001). Although several acidophilic microbes have been reported (Table 1), a very few acid-stable amylases have been studied in adequate detail (Matzke et al., 1997; Sharma et al., 2012). In this review, we have explained possible strategies for improving acid-stable $\alpha$-amylase production to make the process cost-effective. 
TABLE 1 | Archaeal and bacterial acidophiles.

\begin{tabular}{|c|c|c|c|}
\hline Microorganisms & $\begin{array}{c}\text { Optimum } \\
\mathrm{pH}\end{array}$ & $\begin{array}{l}\text { Optimum } \\
\text { temp }\end{array}$ & References \\
\hline Bacillus acidicola & 4 & 37 & $\begin{array}{l}\text { Sharma and Satyanarayana } \\
2010\end{array}$ \\
\hline Leptospirillum ferroxidans & 40 & 1.6 & Zhang et al., 2010 \\
\hline Acidithiobacillus ferrivorans & 29 & 2.1 & Hedrich and Johnson, 201 \\
\hline Acidiphilium organovorum & 37 & 3 & Lobos et al., 1986 \\
\hline Acidiphilium symbioticum & 37 & $3-4$ & Bhattacharyya et al., 1990 \\
\hline Acidiphilium cryptum & $35-40$ & 3 & Harrison, 1981 \\
\hline \multicolumn{4}{|c|}{ MODERATELY THERMOPHILIC BACTERIA } \\
\hline Alicyclobacillus acidocaldarius & $60-65$ & $3-4$ & Mavromatis et al., 2010 \\
\hline Acidomicrobium ferroxidans & 48 & 2 & Clark and Norris, 1996 \\
\hline Sulfobacillus acidophilus & $45-48$ & 2 & Norris et al., 1996 \\
\hline $\begin{array}{l}\text { Sulfobacillus } \\
\text { thermosulfidooxidans }\end{array}$ & $45-48$ & 2 & $\begin{array}{l}\text { Golovacheva and } \\
\text { Karavaiko, } 1978\end{array}$ \\
\hline Alicyclobacillus acidiphilus & 50 & 3 & Matsubara et al., 2002 \\
\hline $\begin{array}{l}\text { Leptospirilum } \\
\text { thermoferrooxidans }\end{array}$ & $45-50$ & $1.6-1.9$ & Golovacheva et al., 1992 \\
\hline Hydrogenobacter acidophilus & 65 & $3-4$ & Shima and Suzuki, 1993 \\
\hline Alicyclobacillus acidoterrestris & $35-55$ & $2-5$ & Orr et al., 2000 \\
\hline \multicolumn{4}{|l|}{ Archaea } \\
\hline Thermogymnomonas acidicola & 60 & 3 & Itoh et al., 2007 \\
\hline Sulfurococcus yellowstonii & $60-65$ & $2-2.5$ & Karavaiko et al., 1994 \\
\hline Sulfolobus metallicus & $65-68$ & $1-4.5$ & Huber and Stetter, 1991 \\
\hline Picrophilus torridus & 60 & 0.7 & Schleper et al., 1995 \\
\hline Thermoplasma acidophilum & 59 & $1-2$ & Darland et al., 1970 \\
\hline Thermoplasma volcanium & 60 & 2 & Segerer et al., 1988 \\
\hline Picrophilus oshimae & 60 & 0.7 & Schleper et al., 1995 \\
\hline \multicolumn{4}{|c|}{ HYPERTHERMOPHILIC ARCHAEA } \\
\hline Acidianus infernus & 90 & 2 & Segerer et al., 1986 \\
\hline Desulfurolobus ambivalens & 81 & 2.5 & Fuchs et al., 1996 \\
\hline Metalloshaera sedula & 75 & 1.7 & Huber et al., 1989 \\
\hline Metallsphaera prunae & 75 & $1-4$ & Fuchs et al., 1996 \\
\hline Sulfolobus acidocaldarius & 80 & $2-3.5$ & Brock et al., 1972 \\
\hline Sulfolobus shibatae & 80 & 3 & Grogan et al., 1990 \\
\hline Sulfolobus yangmingensis & 80 & 4 & Ren-Long et al., 1999 \\
\hline Sulfolobus tengchongensis & 85 & 3.5 & Xiang et al., 2003 \\
\hline Sulfurisphaera ohwakuensis & 84 & 2 & Kurosawa et al., 1998 \\
\hline Acidilobus aceticus & 85 & 3.8 & Prokofeva et al., 2000 \\
\hline
\end{tabular}

\section{NEED FOR ACID-STABLE AMYLASES}

Starch is a ubiquitous reserve polysaccharide in plants and one of the most abundant energy sources. The starch hydrolyzing enzymes such as $\alpha$-amylases, glucoamylases, $\alpha$-glucosidases, and pullulanases have become increasingly attractive for starch industries because of increasing demand for sugar syrups (Sharma and Satyanarayana, 2013a; Elleuche et al., 2014). Moreover, starch hydrolyzing enzymes have attracted attention in ethanol production and account for $25 \%$ of the global enzyme market today (Sharma et al., 2016).

The conventional industrial conversion of starch to glucose consists of a three-step industrial process: in the first step, 25$30 \%$ starch slurry is gelatinized in a jet cooker at $100-105^{\circ} \mathrm{C}$ for 5-10 min, in the second step $\alpha$-amylase and $\mathrm{Ca}^{2+}(50 \mathrm{ppm})$ are added with $\mathrm{pH}$ adjusted to 6.5 for liquefaction, and in the last step, glucoamylase addition leads to the formation of glucose (Figure 1) (Crabb and Mitchinson, 1997; Mehta and Satyanarayana, 2013). A few bottlenecks are associated with the process: firstly, gelatinization at higher temperature $\left(100-105^{\circ} \mathrm{C}\right)$ requires high energy input. Secondly, native $\mathrm{pH}$ of starch slurry is around 3-4.5, thus, a $\mathrm{pH}$ adjustment step is required because $\alpha$-amylases that are commercially available function best at $\mathrm{pH}$ 6-6.5. Thirdly, most of the $\alpha$-amylases are $\mathrm{Ca}^{2+}$-dependent, and thus, $\mathrm{Ca}^{2+}$ is added during the process, which must be removed in the subsequent stages because glucose isomerase used in fructose syrup production is inhibited in the presence of $\mathrm{Ca}^{2+}$. In order to make the process economical and time saving, there has been an emphasis on discovering $\mathrm{Ca}^{2+}$ independent, acidstable and raw starch degrading thermostable $\alpha$-amylases, which can hydrolyze raw starch at sub-gelatinization temperatures bypassing the energy intensive gelatinization, and avoiding $\mathrm{Ca}^{2+}$ addition and $\mathrm{pH}$ adjustment steps (Sharma and Satyanarayana, 2010; Mehta and Satyanarayana, 2016; Sharma et al., 2016).

\section{ACIDOPHILES AND THEIR BIOLOGY}

Among extreme environments, acidic environments are especially interesting because the low $\mathrm{pH}$ of the habitat is a consequence of microbial metabolic activities (e.g., production of acid, deamination of amino acids etc.), and not a condition imposed by the system as in other extreme environments like temperature, radiation and pressure. For example, the extreme conditions of the Tinto River in Southwestern spain are due to the products of metabolic activity of chemolithotrophic microorganisms residing in its water, but not due to the intensive mining activity carried out in the area as believed earlier (Johnson, 1998; González-Toril et al., 2003). Acidophiles are classified as organisms which can withstand and even thrive in acidic environments having $\mathrm{pH}$ values in the range of 1.0 to 5.0. Acidophiles are found in eukaryotes (fungi) as well as prokaryotes (bacteria and archaea) which thrive in a variety of acidic environments, including sulphuric pools and geysers, areas polluted by acid mine drainage, and even our own guts (Baker-Austin and Dopson, 2007; Sharma et al., 2012). Based on the optimum temperature required for growth, acidophiles have been subdivided further into various groups: mesophilic acidophiles (Acidithiobacillus, Ferroplasma, Leptospirillum), moderate thermoacidophiles (Picrophilus torridus) and hyper thermoacidophiles (Acidianus infernus) (Table 1). It has, however, been observed that the most thermotolerant microbes are not the most acid tolerant and vice versa (Auernik et al., 2008). The most thermophilic extreme thermoacidophilic archaeon, Acidianus infernus that grows at $65-95^{\circ} \mathrm{C}\left(\mathrm{T}_{\mathrm{opt}} 90^{\circ} \mathrm{C}\right)$, grows in the $\mathrm{pH}$ range between 5.5 and 1.0, with the optimum around 2.0 (Segerer et al., 1986). The members of archaeal Picrophilaceae are the most acidophilic organisms known and are able to grow at $\mathrm{pH} 0.7$ and $60^{\circ} \mathrm{C}$ (Schleper et al., 1995).

Despite being able to survive in extreme acidic conditions, intracellular $\mathrm{pH}$ of acidophiles is similar to that of neutrophiles 

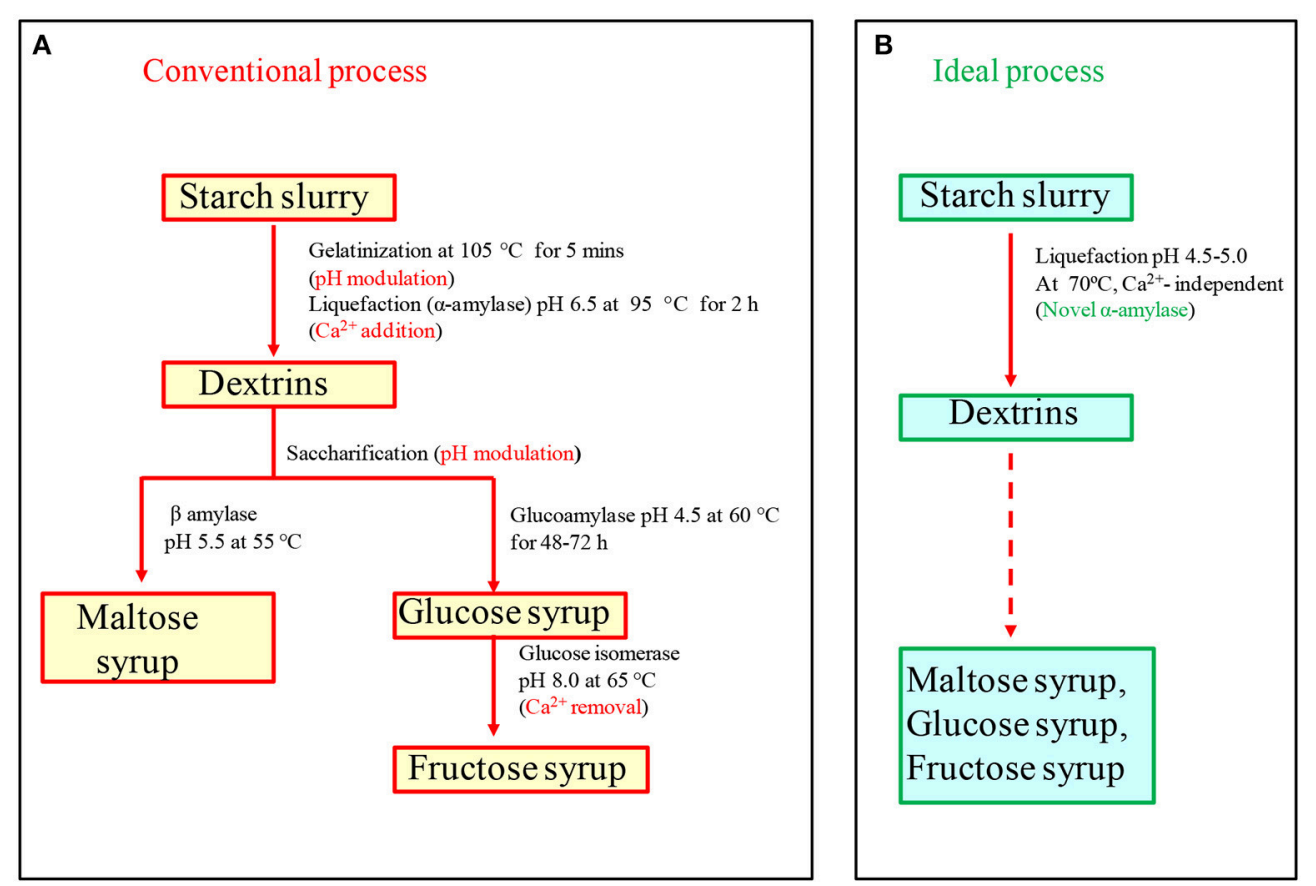

FIGURE 1 | (A) Conventional starch saccharification process needs various $\mathrm{pH}$ modulation steps and salt addition (Ca $\left.{ }^{2+}-50 \mathrm{ppm}\right)$ and removal steps, which increase cost of the process. (B) In ideal starch saccharification, $\mathrm{pH}$ modulation and calcium addition can be eliminated with the help of acid-stable and $\mathrm{Ca}^{2+}$ independent amylase (modified with permission from Sharma and Satyanarayana, 2013a).

because macromolecules such as DNA become unstable at acidic $\mathrm{pH}$. Their $\mathrm{pH}$ gradients $\left[\mathrm{pH}\right.$ gradient $(\mathrm{pH})=\mathrm{pH}_{\mathrm{in}}$ - $\left.\mathrm{pH}_{\text {out }}\right]$, however, remain several orders of magnitude greater than neutrophiles. In order to survive, acidophiles have evolved multiple mechanisms such as highly impermeable cell membranes, small genomes for ease in maintenance, genes for organic acid degradation, DNA and protein repair systems, and a predominance of secondary transporters to remove protons once they have entered cytoplasm (Figure 2) (Johnson, 1998; Baker-Austin and Dopson, 2007; Sharma et al., 2016). Acidophiles are the most widely distributed in the bacterial and archaeal domains (Table 1) and have numerous biotechnological applications (Sharma et al., 2012; Elleuche et al., 2014; Mehta and Satyanarayana, 2016).

\section{$\alpha$ - AMYLASE PRODUCING ACIDOPHILES}

Despite extensive research on acidophiles, very few have been exploited for commercial purposes. Matzke et al. (1997) reported $\alpha$-amylase from acidophilic bacterium Alicyclobacillus acidocaldarius, which is thermostable and acidstable with a molecular mass of $140 \mathrm{kDa}$, with optimum temperature and $\mathrm{pH}$ of $75^{\circ} \mathrm{C}$ and 3.0, respectively. Bai et al. (2012) reported another $\alpha$-amylase from Alicyclobacillus sp. A4 with a molecular mass of $64 \mathrm{kDa}$ and optimal activity at $75^{\circ} \mathrm{C}$ and $\mathrm{pH} 4.2$. In still another report, an $\alpha$-amylase from the acidophilic bacterium Bacillus sp. DR90, isolated from Dig Rostam hot mineral spring (Iran), was investigated. The enzyme was active in a wide range of $\mathrm{pH}$ and temperature having optimal activity at $\mathrm{pH} 4.0$ and $75^{\circ} \mathrm{C}$ with a molecular mass of $76 \mathrm{kDa}$ (Asoodeh et al., 2014). Laderman et al. (1993) reported a thermoacidophilic $\alpha$-amylase from Pyrococcus furiosus which was optimally active at $\sim 100^{\circ} \mathrm{C}$ and $\mathrm{pH} 5.5-6.0$. The enzyme is a homodimer with a subunit molecular mass of $66 \mathrm{kDa}$. Recently a $\mathrm{Ca}^{2+}$-independent, acid-stable $\alpha$-amylase (Baamy) from the acidophilic bacterium Bacillus acidicola TSAS1 has been investigated in detail. This has been found to be a potential candidate for saccharification of starch at its native $\mathrm{pH}$ of 3.0-4.5 with $\mathrm{T}_{1 / 2}$ of $25 \mathrm{~min}$ at $70^{\circ} \mathrm{C}$ (Sharma and Satyanarayana, 2010).

\section{PRODUCTION OF ACID-STABLE AMYLASES}

At commercial level, amylolytic enzymes are being produced from Bacillus spp. (B. licheniformis, B. stearothermophilus and B. amyloliquefaciens) and filamentous fungi such as Aspergillus oryzae and A. niger (http://www.novozymes.com/) (Sharma and Satyanarayana, 2013a; Sharma et al., 2016). They are the preferred sources because of their rapid growth rates, economical production and ability to secrete a large quantity of amylases, which lack either acid stability or thermostability. Amylases from acidophiles have tremendous potential to replace neutrophilic enzymes because they are active in the acidic range. Production on a commercial scale is, however, a major bottleneck because of low titres of extracellular amylases secreted by acidophilic and acid tolerant microbes (Table 4). Schwermann et al. (1994) recorded maximum amylase production $\left(90 \mathrm{U} \mathrm{mL}^{-1}\right)$ in the 


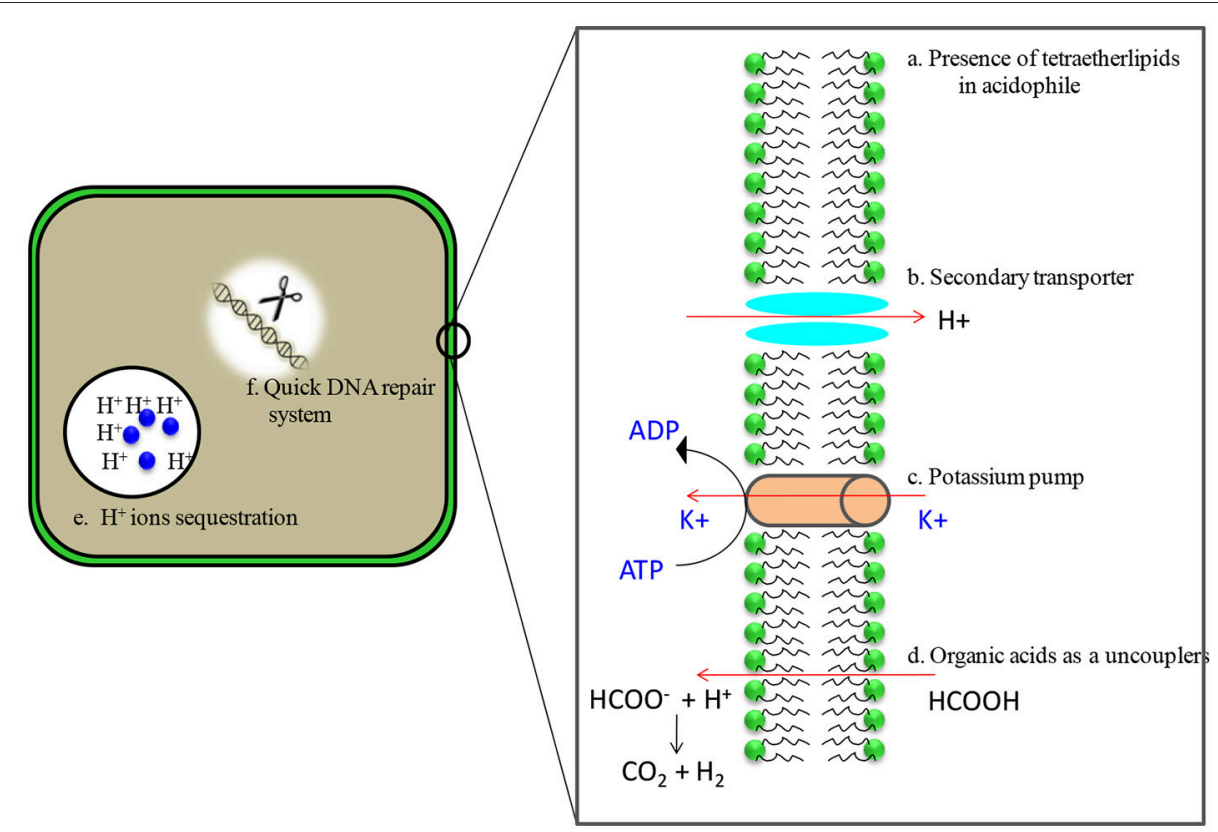

FIGURE 2 | Adaptations of acidophilic microbes in acidic environments. (a) membranes are characterized by the presence of tetraether lipids which are less susceptible to acid hydrolysis (b) Presence of putative proton efflux system that includes secondary transporters ATPases, antiporters and symporters (c) high number of putative cation transporters, possibly involved in the generation of Donnan potential (d) carry genes encoding the enzymes of organic acid degradation (e) contain cytoplasmic buffering molecules which have capacity to sequester protons (f) presence of heat shock proteins/chaperones and quick DNA repair system.

presence of maltose as compared to other carbon sources used in the production medium. Bai et al. (2012) reported a $2.3 \mathrm{U}$ $\mathrm{mL}^{-1} \alpha$-amylase production in Alicyclobacillus sp. A4 after $48 \mathrm{~h}$ in the presence of starch as carbon source. A few researchers have attempted multiple strategies to increase the extracellular acid-stable amylase titres (Table 4). Kanno (1986) improved $A$. acidocaldarious A2 strain by using UV/enrichment method for $\alpha$-amylase production. A total of 11 -fold increase in the enzyme titre was achieved as compared to the wild type strain (220 U $\mathrm{mL}^{-1}$ ). Brown et al. (1990) attained a low constitutive level of $\alpha$-amylase from Pyrococcus furiosus in the presence of simple sugars, while polysaccharides with $\alpha-1,4$ linkages stimulated production. The maximum yield of extracellular $\alpha$-amylase was achieved $\left(100 \mathrm{UmL}^{-1}\right)$ in $P$. furiosus in the presence of pullulan as a carbon source in submerged fermentation at $98^{\circ} \mathrm{C}$.

A detailed investigation was carried out on the production of $\alpha$-amylase by $B$. acidicola in submerged fermentation. Conventional "one-variable-at-a time" and statistical approaches have been used for optimizing the cultural parameters (Sharma and Satyanarayana, 2011). $\alpha$-Amylase production by B. acidicola was high in the presence of soluble starch (2\%) as a carbon source. Among nitrogen sources tested, tryptone (HIMEDIA) [0.5\%] in combination with yeast extract $(0.5 \%)$ supported a high enzyme titre. The $\alpha$-amylase produced by $B$. acidicola displayed a high activity $(8 \mathrm{U} / \mathrm{mL})$ at $\mathrm{pH} 4.0$ and $37^{\circ} \mathrm{C}$ after $44 \mathrm{~h}$. The enzyme production was high when the cells are in stationary phase as in Geobacillus thermoleovorans (Uma Maheswar Rao and Satyanarayana, 2003). Further statistical approaches [PlackettBurman design and Response Surface Methodology (RSM)] were employed for optimizing $\alpha$-amylase production by B. acidicola in submerged fermentation. When the effect of 11 variables on $\alpha$ amylase production was assessed using Plackett-Burman design, four variables (starch, $\mathrm{K}_{2} \mathrm{HPO}_{4}$, inoculum size, and temperature) were identified to significantly affect enzyme production. In order to control process parameters like aeration, uniform distribution of nutrients, and heat and oxygen transfer for $\alpha$ amylase production by $B$. acidicola; fermentation was carried out in a $7 \mathrm{~L}$ laboratory fermentor. A reduction in fermentation time for attaining the peak was recorded; this could be due to improvement in mixing of nutrients and the control of dissolved oxygen (Kumar and Satyanarayana, 2007). Further, a 2.9-fold enhancement in enzyme production was attained due to fedbatch fermentation as compared to that in the initial unoptimized medium $\left(3.5 \mathrm{U} \mathrm{mL}^{-1}\right)$ (Sharma and Satyanarayana, 2011).

Bacillus acidicola is amenable to solid state cultivation like some other Bacillus spp. (Babu and Satyanarayana, 1995; Chen et al., 2005). Therefore, production of $\alpha$-amylase by solid state fermentation was also attempted in order to find the prospects of using a wide range of agro-industrial residues as substrates (Babu and Satyanarayana, 1995; Sharma and Satyanarayana, 2012b). A peak in enzyme production was reached in $72 \mathrm{~h}$, when $10 \mathrm{~g}$ of wheat bran was used in $250 \mathrm{~mL}$ Erlenmeyer flasks as reported for the production of $\alpha$-amylase by Bacillus coagulans (Babu and Satyanarayana, 1995). In contrast, $5 \mathrm{~g}$ wheat bran per $250 \mathrm{~mL}$ flask was used for $\alpha$-amylase production by B. amyloliquefaciens (Gangadharan et al., 2006). Bacillus acidicola secreted high enzyme titre at $\mathrm{a}_{\mathrm{w}}$ (water activity) 0.95; below this, $\alpha$-amylase production declined, with no growth and 
enzyme production below $\mathrm{a}_{\mathrm{w}} 0.85$, indicating that the bacterium is desiccation sensitive. Supplementation of wheat bran with ammonium sulfate supported a high enzyme titre. The addition of nitrogen sources to the solid substrates had been shown to enhance the production of various enzymes including $\alpha$ - amylase in solid state fermentation (SSF) (Pedersen and Nielsen, 2000). Moisture (substrate:water, 1:3.5), starch (2.9\%) and ammonium chloride $(0.38 \%)$ supported a high enzyme titre in B. acidicola. Statistical optimization of $\alpha$-amylase production in SSF using response surface methodology led to 5.6 -fold $[28 \pm 2.3 \mathrm{U} / \mathrm{g}$ dry bacterial bran (DBB)] increase in the titre as compared to unoptimized conditions ( $\pm 1.1 \mathrm{U} / \mathrm{g} \mathrm{DBB}$ ) (Sharma and Satyanarayana, 2012b).

\section{CLONING AND EXPRESSION OF ACID-STABLE $\alpha$-AMYLASE ENCODING GENES}

Despite extensive efforts, attaining higher enzyme titres by wild type microbial strains is a major hurdle for their commercialization. By cloning and expressing acid-stable amylase encoding genes from acidophiles in mesophilic hosts such as E. coli, Pichia pastoris or Bacillus subtilis, the production can be made cost-effective (Table 4). However, improper folding and differences in codon usage often hinder over production of enzymes in heterologous expression systems (Sharma et al., 2012). In order to overcome these bottlenecks, researchers use codon optimized synthetic genes or different host variants (Elleuche et al., 2014; Ranjan and Satyanarayana, 2016). Acidstable $\alpha$-amylase gene from Bacillus sp. DR90 was successfully cloned in E. coli BL21 and expressed as an intracellular active protein. After induction, specific activity was around $600 \mathrm{U} / \mathrm{mg}$ (Asoodeh et al., 2010). Matzke et al. (1997) cloned acid-stable $\alpha$-amylase gene from Alicyclobacillus acidocaldarius in E. coli. The enzyme was intracellular and the optimum temperature for recombinant acid-stable $\alpha$-amylase was slightly lower than that of the native enzyme. Extracellular acid-stable $\alpha$-amylase encoding gene of $P$. furiosus (PFA) was cloned and expressed in E. coli (Dong et al., 1997). The recombinant acid-stable $\alpha$ amylase was mainly expressed in the form of insoluble inclusion bodies. An improved purification method was developed by Wang et al. (2007). The solubilization of the inclusion bodies was achieved by treatment at $90^{\circ} \mathrm{C}$ for $3 \mathrm{~min}$ in BrittonRobinson buffer at $\mathrm{pH}$ 10.5. After solubilization, a total of $58,000 \mathrm{U} / \mathrm{g}$ wet cells yield was obtained. In another study, Peng et al. (2016) co-expressed PFA with chaperones in E. coli. Both chaperonin and a small heat shock protein (sHSP) increased the solubility of PFA to a certain degree, while pre-folding seemed to be the most efficient that increased the enzyme activity to about $60,000 \mathrm{U} \mathrm{g}^{-1}$ wet weight over that of $5,000 \mathrm{U} \mathrm{g}^{-1}$ wet weight without chaperone. Wang et al. (2016) produced soluble PFA by expressing PFA in B. amyloliquefaciens. The yield of PFA was 2,000 $\mathrm{U} \mathrm{mL}^{-1}$ of supernatant and 2,714 $\mathrm{U}$ $\mathrm{mL}^{-1}$ of total culture. Zhu et al. (2017) expressed PFA in Nicotiana tabacum and found that plant produced PFA forms functional aggregates with an accumulation level up to $3.4 \mathrm{~g} \mathrm{~kg}^{-1}$ fresh weight. The aggregates were functional without requiring refolding. As stated above, several attempts have been made to increase acid-stable $\alpha$-amylase titres. Intracellular accumulation and inclusion body formation make them impractical for industrial applications (Grzybowska et al., 2004; Wang et al., 2007).

A truncated $1,441 \mathrm{bp}$ acid-stable $\alpha$-amylase gene encoding 479 amino acid $\alpha$-amylase (Ba-amy) of $B$. acidicola was successfully cloned and expressed in active form in E. coli. Various approaches have been developed for efficient secretion of proteins such as increasing the permeability of the outer membrane chemically (adding EDTA, glycine, and Triton X100) and by enzymatic (lysozyme) treatments (Sharma and Satyanarayana, 2012a; Parashar and Satyanarayana, 2016a). The purified recombinant $\alpha$-amylase was active at $\mathrm{pH} 4.0$ and $60^{\circ} \mathrm{C}$, and retained all characteristics like that of the native $\alpha$-amylase.

The methylotrophic yeast Pichia pastoris has emerged as an important production host for extracellular production of proteins for both basic research and industrial applications (Cregg et al., 2009; Spohner et al., 2015). Codon usage analysis of acid-stable Ba-amy revealed the feasibility of its expression in Pichia pastoris. In order to increase extracellular production of acid-stable $\alpha$-amylase, $B a$-amy was cloned and expressed in $P$. pastoris under dual promoters (GAP and $A O X)$ and fused with $\alpha$-factor secretion signal peptide. Mixed fed batch and high cell density cultivation experiments were performed which led to 15- and 7- fold higher extracellular enzyme titres than that of the wild type $B$. acidicola and recombinant E. coli, respectively (Parashar and Satyanarayana, 2016b). The recombinant acid-stable Ba-amy purified from $P$. pastoris was biochemically characterized, which revealed kinetic properties and thermostability of glycosylated acid-stable Ba-amy to be similar to those of the recombinant acid-stable Ba-amy expressed in E. coli. The engineered Ba-amy (Ba-Gt-amy) was also cloned and expressed in $P$. pastoris (Parashar and Satyanarayana, 2017a). The combination of multiple transformations and post-transformational vector amplification (PTVA) and high cell density cultivation in fermentor led to a very high production $(750 \mathrm{U} / \mathrm{mL})$ of the chimeric Ba-Gt-amy (Parashar and Satyanarayana, 2017a).

\section{STRUCTURAL CHARACTERISTICS OF ACID-STABLE $\alpha$-AMYLASE}

Although the adaptation of acidstable enzymes to low $\mathrm{pH}$ has not been explored in greater detail, one explanation for $\mathrm{pH}$ stability has been offered from the modeling of $\alpha$-amylases from $B$. acidicola and other acid-stable amylases. A detailed investigation revealed that the acid stability and activity at acidic $\mathrm{pH}$ could be attributed to the surface charge density and amino acid composition of these proteins (Table 2). A prominent feature of acidstable $\alpha$-amylases is the excess of glutamic and aspartic acid $(\mathrm{D}+\mathrm{E})$ residues on their surface as compared to their closest relatives. Moreover, the enzyme contains less positively charged amino acid residues $(\mathrm{K}+\mathrm{R}+\mathrm{H})$ than their neutrophilic counterparts that leads to reduced positive charge 
TABLE 2 | Amino acid composition (\%) and other characteristics of acidic, basic and neutral amylases.

\begin{tabular}{lccccclc}
\hline Characteristics & $\begin{array}{c}\text { Basic amino acid } \\
\text { (H + R + K) }\end{array}$ & $\begin{array}{c}\text { Acidic amino } \\
\text { acid } \\
\text { (D + E) }\end{array}$ & $\begin{array}{c}\text { Total amino } \\
\text { acid }\end{array}$ & PI & $\begin{array}{c}\text { Molecular } \\
\text { weight }\end{array}$ & Source & Reference \\
\hline Acidic & 6.4 & 10.5 & 1276 & 4.36 & 137 & Alicyclobacillus acidocaldarius & Matzke et al., 1997 \\
Acidic & 11.1 & 10.9 & 626 & 5.53 & 68 & Bacillus sp. DR90 & Asoodeh et al., 2014 \\
Acidic & 11.7 & 11.9 & 479 & 5.41 & 62 & B. acidicola & Sharma and Satyanarayana, \\
Acidic & 10.4 & 12.9 & 435 & 4.82 & 50 & Pyrococcus furiosus & Laderman et al., 1993 \\
Basic & 10.5 & 15.2 & 923 & 4.61 & 103 & Bacillus halodurans & Murakami et al., 2007 \\
Basic & 9.3 & 15.5 & 922 & 4.44 & 102 & Bacillus sp. & Shirokizawa et al., 1990 \\
Neutral & 15.4 & 12.9 & 483 & 6.05 & 55 & Bacillus licheniformis & Joyet et al., 1984 \\
Neutral & 15.7 & 15.7 & 488 & 5.62 & 57 & Geobacillus thermoleovorans & Mehta and Satyanarayana, 2014 \\
\hline
\end{tabular}

H, Histidine; R, Arginine; K, lysine; D, aspartic acid; E, Glutamic acid; pl, isoelectronic point.

density at the surface of the protein (Figure 2)(Reed et al., 2013). This effect was interpreted as follows: if the proteins were to possess a large content of positively charged residues $(\mathrm{K}+\mathrm{R})$, the positive charges at the surface will repel each other, leading to unfolding of the protein. On the other hand, protonation of the negatively charged group increases at lower $\mathrm{pH}$ that leads to reduction in the negative charge, which aids in stabilizing proteins in acidic conditions. If such proteins were to possess a large excess of negative groups, unfolding might also occur above the isoelectric point of the protein due to disruption of stabilizing structural interactions. In order to be stable and active in a broad $\mathrm{pH}$ range, these groups of proteins must have reduced number of $\mathrm{D}+\mathrm{E}$ residues, which is compensated by an increase in the number of polar residues (Matzke et al., 1997; Schäfer et al., 2004; Reed et al., 2013). These characteristics were also found in other proteins. Huang et al. (2005) reported a high number of acidic residues on the surface of proteins, which causes repulsion due to excess negative charges resulting instability of proteins at high $\mathrm{pH}$. However, a few exceptions have been found to this rule. Schäfer et al. (2004) reported thermo-acid-stable maltose-binding protein from Alicyclobacillus acidocaldarius. This protein has higher content of basic residues exposed on its surface, while most acidic residues are buried in the interior. As a consequence, this protein has a highly positive surface charge. This study suggested that there are multiple factors responsible for the acid-stability of proteins.

Another theory, a change in the $\mathrm{pH}$ activity of the amylases is depends the $\mathrm{pKa}$ of the catalytically important residues which are known to be influenced by the electrostatic field. It has been hypothesized that slight change in the pKa values of the catalytic residues can change the $\mathrm{pH}$ activity profile of the enzyme (Nielsen et al., 1999; Nielsen and Borchert, 2000). The pKa of catalytic residues in the active site can be altered by mutating selected residues that can alter the hydrogen bonding network, solvent accessibility or change in the net charge of the molecule (Nielsen and Borchert, 2000). This can be explained as follows: active site residues must be in a catalytically competent protonation state for the enzyme to be active. Thus the proton donor (Glu) is required to be protonated, while the nucleophile (Asp) must be
TABLE 3 | Distinguishable properties of acid-stable and neutral $\alpha$-amylases.

\begin{tabular}{lcc}
\hline Characteristics & Acidstable $\alpha$-amylases & Neutral $\alpha$-amylases \\
\hline pH range & $3.0-6.0$ & $6.5-8.0$ \\
Temperature range $\left({ }^{\circ} \mathrm{C}\right)$ & $40-115$ & $37-90$ \\
Molecular weight $(\mathrm{kDa})$ & $41-160$ & $12.5-70$ \\
$\mathrm{pl}$ & $3.4-4.8$ & $5.0-7.1$ \\
Acid-stablity & $3.5-5.5$ & Unstable \\
Thermostability $\left({ }^{\circ} \mathrm{C}\right)$ & $60-80$ & Unstable \\
Release of CNP from CNP- $\alpha$-G3 G3 Suppressed by KSCN & Stimulated by KSCN \\
Cleavage of G5 & $\mathrm{GGG}(\alpha)+\mathrm{GG}$ & $\mathrm{GG}+\mathrm{GGG}(\alpha / \beta)$ \\
Number of subsites & 5 & $7-9$
\end{tabular}

Modified from Sharma and Satyanarayana (2013a).

negatively charged. If an $\alpha$-amylase is stable over the entire $\mathrm{pH}$ range, it is feasible that the $\mathrm{pH}$-activity profile can be changed if the pKa value of either the nucleophile or the proton donor is changed. Typically, charged residues are inserted in the vicinity of the titrable group to change the immediate environment of the active site of enzymes (Wind et al., 1998; Nielsen et al., 1999; Nielsen and Borchert, 2000). In several cases, it has been observed that $\mathrm{pH} \pm$ activity profiles shifted in the opposite direction as compared to the shift predicted from electrostatic calculations. This strongly suggests that electrostatic effects cannot be the best method to alter the optimum $\mathrm{pH}$ for enzymes. Secondary structural content does not appear to vary greatly in different amylases, which suggests that it is not a contributing factor.

Acid-stable $\alpha$-amylases appear to degrade starch essentially by the same mechanism as neutrophilic $\alpha$-amylases despite their distinguishing characteristics (Table 3). This contention is based on the deduction that the $\alpha$-amylase from acid-stable and neutrophilic members conserved the same charge at the catalytic active site (Figure 3). Moreover, multiple amino acid alignments and site directed mutagenesis revealed that acid-stable amylases conserved same catalytic residues (Asp189, Glu320, and Asp401) like that of their neutrophilic counterparts (Figure 4). Hence, the acid stability of amylases has minor effect on their catalytic sites (Sharma and Satyanarayana, 2013b). 
TABLE 4 | Production profile of wild and recombinant acid-stable amylases from various acidophiles.

\begin{tabular}{|c|c|c|c|c|c|c|c|}
\hline Source & Optimum pH & $\begin{array}{l}\text { Production by the } \\
\text { wild strain } \\
U \mathrm{~mL}^{-1}\end{array}$ & $\begin{array}{l}\text { Production in the } \\
\text { recombinant } \\
\text { E. coli }\left(\mathrm{U} \mathrm{mg}^{-1}\right)\end{array}$ & $\begin{array}{c}\text { Production in the } \\
\text { recombinant } \\
\text { P. pastoris } \\
\mathrm{U} \mathrm{mL}^{-1}\end{array}$ & $\begin{array}{l}\text { Production in } \\
\text { Bacillus spp. } \\
\qquad \mathrm{mL}^{-1}\end{array}$ & $\begin{array}{l}\text { Production } \\
\text { in } \\
\text { plant }\end{array}$ & References \\
\hline Alicyclobaillus sp. A4 & 4.2 & 2.3 & - & - & - & - & Bai et al., 2012 \\
\hline Alicyclobacillus acidocaldarious & - & - & 0.33 & - & - & - & Schwermann et al., 1994 \\
\hline Alicyclobacillus acidocaldarius & - & 0.1 & - & - & - & - & Schwermann et al., 1994 \\
\hline P. furiosus & 5.5 & - & 138.0 & - & - & - & Wang et al., 2007 \\
\hline P. furiosus & 5.5 & 100.0 & - & - & - & - & Brown et al., 1990 \\
\hline P. furiosus & 5.5 & - & - & - & 2714 & - & Wang et al., 2016 \\
\hline P. furiosus & 5.5 & - & - & - & - & $\begin{array}{l}34.0 \mathrm{~g} \mathrm{Kg}^{-1} \\
\text { fresh weight }\end{array}$ & Zhu et al., 2017 \\
\hline
\end{tabular}
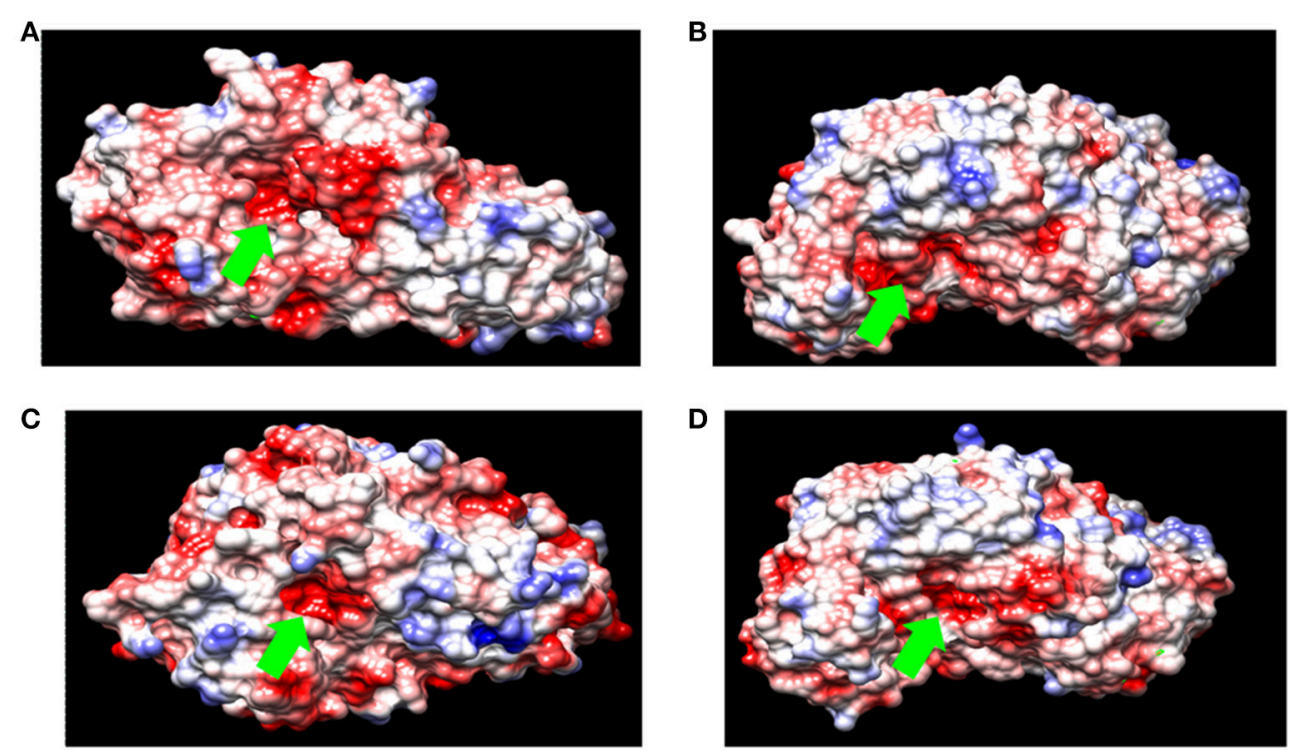

FIGURE 3 | Surface charge density of (A) $\alpha$-amylase from B. acidicola (B) $\alpha$-amylase from Bacillus sp. DR90 (C) $\alpha$-amylase from B. licheniformis (D) $\alpha$-amylase from Geobacillus thermoleovorans. (red for negative potential, white near neutral and blue for positive potential. Green arrow indicates catalytic active site of amylase).

\section{PROTEIN ENGINEERING OF $\alpha$-AMYLASES FOR ACID STABILITY AND STARCH SACCHARIFICATION}

Several methods of protein engineering are employed for improving acid stability of thermostable $\alpha$-amylases to make them suitable for industrial applications, although success achieved so far is negligible. Nielsen et al. (1999) modified thermostable $\alpha$-amylase from Bacillus licheniformis by using site directed mutagenesis, which was predicted to change the
pKa values of the catalytic residues. The observations suggested that $\mathrm{pH} \pm$ activity profiles of mutants which change the net charge on the molecule were significantly different from the wild-type $\mathrm{pH} \pm$ activity profile. The differences were, however, difficult to correlate with the electrostatic field changes calculated. In another study, two amino acids of $\alpha$-amylase from $B$. licheniformis were substituted (Leu134 to Arg and Ser320 to Ala) for acid tolerance, and the mutated gene was expressed in Bacillus subtilis WB600. The $\alpha$-amylase variants were found to be more acid tolerant than the native protein. The optimum $\mathrm{pH}$ and stable 


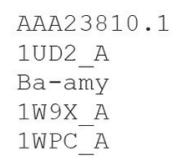

AAA23810.1 1UD2 A

Ba-amy

1 W9X A

$1 \mathrm{WPC}^{-} \mathrm{A}$
---MRNPTLLQCFHWYYPEGGSSWPELAERADGFNDIGINMVWLPPAYKGASGGYSVGYD --DGLNGTMMOYYEWHLENDGOHWNRLHDDAAALSDAGITAIWIPPAYKGNSO-ADVGYG ----ENGTMMQYFEWYLPDDGTLWTKVANEANNLSSLGITALWLPPAYKGTSR-SDVGYG ----TNGTMMQYFEWHLPNDGQHWNRLRDDASNLRNRGITAIWIPPAWKGTSQ-NDVGYG HHNGTNGTMMQYFEWYLPNDGNHWNRLNSDASNLKSKGITAVWIPPAWKGASQ-NDVGYG

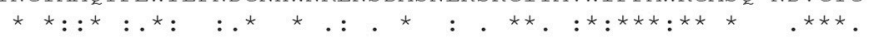

SYDLFDLGEFDQKGSIPTKYGDKAQLLAAIDALKRNDIAVLLDVVVNHKMGVDEKEAIRV AYDLYDLGEFNQKGTVRTKYGTKAQLERAIGSLKSNDINVYGDVVMNHKMGADFTEAVQA VYDLYDLGEFNQKGTVRTKYGTKAOYLQTIQAAHAAGMQVYADVVFDHKGGADGTEWVDA AYDLYDLGEFNQKGTVRTKYGTRSQLESAIHALKNNGVQVYGDVVMNHKGGADATENVLA AYDLYDLGEFNQKGTVRTKYGTRSQLQAAVTSLKNNGIQVYGDVVMNHKGGADATEMVRA

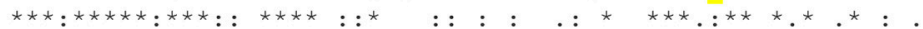

QRVNADDRTQIDEEIIECEGWTRYTFPARAGEYSOFIWDFKCFSGIDHIENPDE-DGIFK VQVNPTNRWQDISGAYTIDAWTGFDFSGRNNAYSDFKWRWFHFNGVDWDQRYQE-NHIFR VEVNPSDRNQEISGTYQIQAWTKFDFPGRGNTYSSFKWRWYHFDGVDWDESRKL-SRIYK VEVNPNNRNOEISGDYTIEAWTKFDFPGRGNTYSDFKWRWYHFDGVDWDQSROFONRIYK VEVNPNNRNQEVTGEYTIEAWTRFDFPGRGNTHSSFKWRWYHFDGVDWDQSRRLNNRIYK

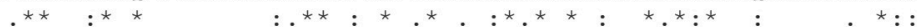

57
57
55
55
59


117
117
115
115
119

IVNDYTGEGWNDQVDDELGNFDYLMGENIDFRNHAVTEEIKYWARWVMEQTQCDGFRIDA 236 F----ANTNWNWRVDEENGNYDYLLGSNIDFSHPEVQDELKDWGSWFTDELDLDGYRLDA 232 FR--GIGKAWDWEVDTENGNYDYLMYADLDMDHPEVVTELKNWGKWYVNTTNIDGFRLDA 232 FR--GDGKAWDWEVDSENGNYDYLMYADVDMDHPEVVNELRRWGEWYTNTLNLDGFRIDA 233 FR--GHGKAWDWEVDTENGNYDYLMYADIDMDHPEVVNELRNWGVWYTNTLGLDGFRIDA 237

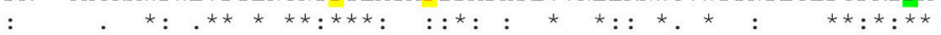

VKHIPAWFYKEWIEHVQEVAPKPLFIVAEYWSHEVDKLQTY IDQVEGKTMLFDAPLQMKF IKHIPFWYTSDWVRHQRNEADQDLFVVGEYWKDDVGALEFYLDEMNWEMS LFDVPLNYNF VKHIKFSSFPDWLSYVRSQTGKPLFTVGEYWSYDINKLHNYITKTNGTMSLEDAPLHSKF VKHIKYSETRDWLTHVRNATGKEMFAVAE EWKNDLGALENYLNKTNWNHSVEDVPLHYNL VKHIKYSFTRDWINHVRSATGKNMFAVAEFWKNDLGAIENYLQKTNWNHSVEDVPLHYNL

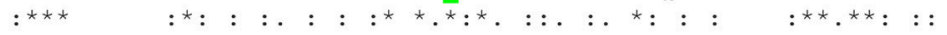

HEASRMGRDYDMTQIFTGTLVEADPFHAVTLVANHDTQPLQALEAPVEPWEKPLAYALIL YRASQQGGSYDMRNILRGSLVEAHPMHAVT FVDNHDTQPGESLESWVADWFKPLAYATIL YTASKSGGAFDMRTLMTNTLMKDQPTLAVTFVDNHDTEPVQALQSWVDPWEKPLAYAFIL YNASNSGGNYDMAKLLNGTVVQKHPMHAVTFVDNHDSQPGESLESFVQEWFKPLAYALIL YNASKSGGNYDMRN I FNGTVVQRHPSHAVTFVDNHDSQPEEALESFVEEWFKPLAYALTL

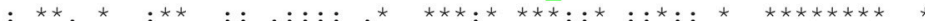

LRENGVPSVFYPDLYGAHYEDVGGDGQTYPIDMPIIEQLDELILARORFAHGVQTLFFDH TREGGYPNVFYGDYYGI PNDNISA---------KKDMI DELLDARQNYAYGTQHDYFDH TRQEGYPCVFYGDYYGIPQYNIPS----------LKSKIDPLLIARRDYAYGTQHDYLDH TREQGYPSVFYGDYYGIPTHSVPA----------MKAKIDPI LEARQNFAYGTQHDYFDH TREQGYPSVFYGDYYGIPTHGVPA---------MRSKIDPILEARQKYAYGKQNDYLDH

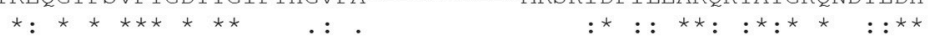

PNCIAFSRSGTDEFPG--CVVVMSNGDDGEKTI HLGENYGNKTWRDFLGNRQERVVTDEN WDVVGWTREGSSSRPNSGLATIMSNGPGGSKWMYVGRQNAGQTWTDLTGNNGASVTINGD SDI IGWTREGVTEKPGSGLAALITDGPGGSKWMYVGKQHAGKVFYDLTGNRSDTVTINSD HNI I GWTREGNTTHPNSGLAT IMS DGPGGEKWMYVGQNKAGQVWHDITGNKPGTVTINAD HNI IGWTREGNTAHPNSGLATIMSDGAGGSKWMFVGRNKAGQVWSDITGNRTGTVTINAD

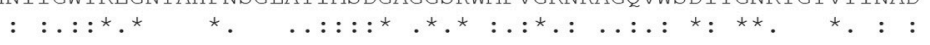

\section{4}

462

462

463

467

GEATFFCNGGSVSVWVIEEVI 495

GWGEFFTNGGSVSVYVNQ--- 480

GWGEFKVNGGSVSVWVP---- 479

GWANFSVNGGSVSIWVKR--- 481

GWGNFSVNGGSVSIWVNK--- 485

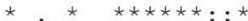

FIGURE 4 | Multiple sequence alignment of different $\alpha$-amylases. Residues responsible for calcium binding sites are highlighted in yellow color. Catalytically important residues are shown in green color. AAA23810.1- $\alpha$-amylase from Escherichia coli; 1UD2_A: Calcium free $\alpha$-amylase from Bacillus Sp. Strain Ksm-K38; Ba-amy: $\alpha$-amylase from B. acidicola; 1W9X_A: Bacillus halmapalus $\alpha$-amylase; 1WPC_A: maltohexaose producing $\alpha$-amylase from Bacillus sp. 707. [( $\left.{ }^{*}\right)$ the residues are identical in all sequences; (:) the conserved substitutions; (.) semi-conserved substitutions].

$\mathrm{pH}$ range of the mutein (mutated protein) were 4.5 and $4.0-$ 6.5, as compared to 6.5 and $5.5-7.0$ as the optimum $\mathrm{pH}$ and $\mathrm{pH}$ stability range of the native protein. It has been postulated that mutations changed the net charge on the substituted residues, which influenced the pKa values of catalytically important amino acid residues (E261 and/or D328) (Liu et al., 2008a, 2012).

Yang et al. (2013) engineered amylase from Bacillus subtilis for improving protein stability and catalytic efficiency under acidic 
conditions by site-directed mutagenesis. Based on the analysis of three dimensional structure model, four basic histidine (His) residues (His222, His275, His293, and His310) in the catalytic domain were replaced with acidic aspartic acid (Asp) residues.
The acid stability of the enzyme was significantly enhanced after mutation. It has been observed that the hydrogen bonds and salt bridges increased after mutation around the catalytic domain. The higher $\mathrm{pKa}$ of Asp was responsible for destabilizing the

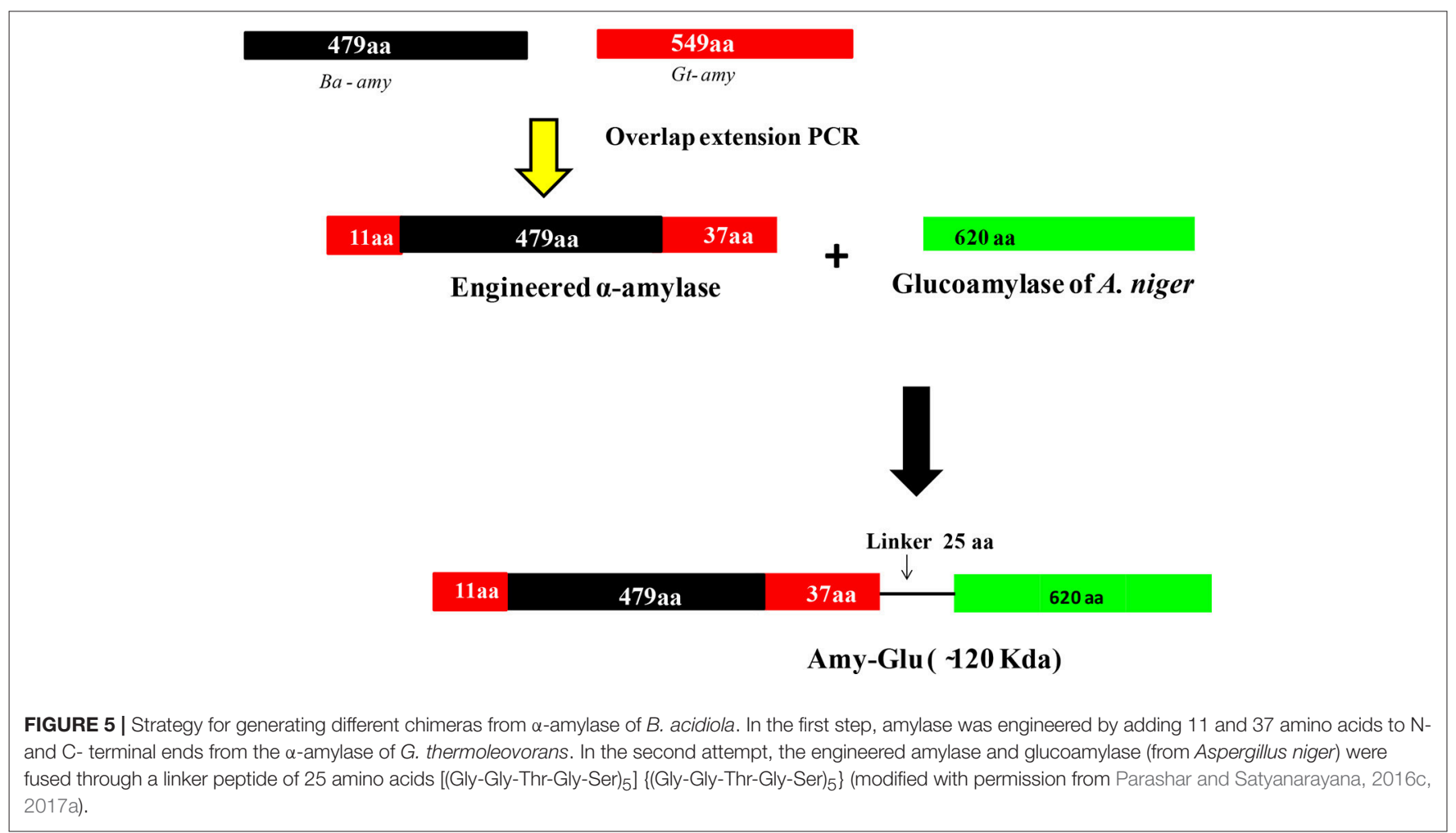

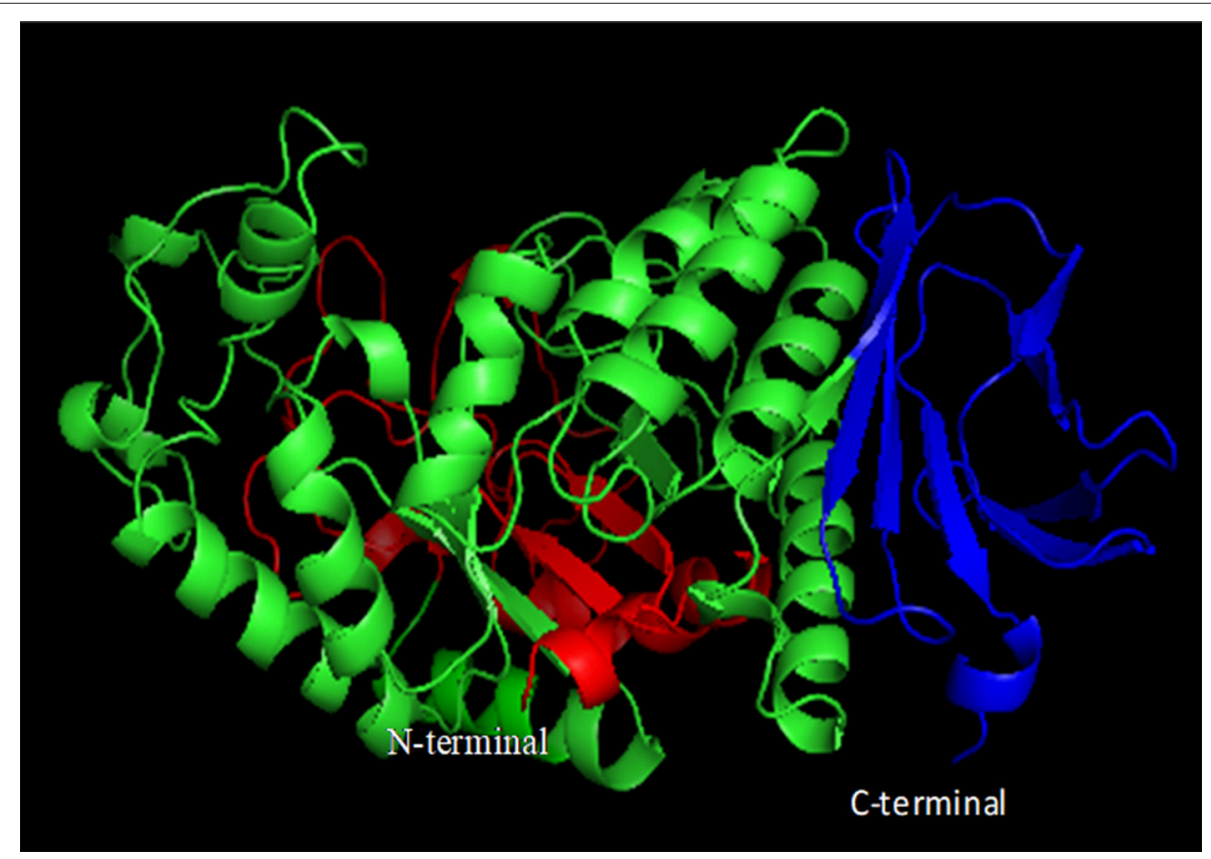

FIGURE 6 | Domain organization of $\alpha$-amylases. Domain A is shown in green, domain B in red, and domain C in blue (constructed using PyMOL). 
protonated form of Glu250, resulting in a decrease of the $\mathrm{pKa}$ value of Glu250. These changes around the catalytic domain have been suggested for improvement in protein stability and catalytic efficiency at low $\mathrm{pH}$. Similar efforts have also been made for improving the $\mathrm{pH}$ stability of amylases by protein engineering (Shaw et al., 1999; Priyadharshini et al., 2010; Liu et al., 2012).

Despite a few strategies reported in the literature for improving acid stability of proteins (Liu et al., 2008a,b, 2012; Yang et al., 2013), there is no universal strategy that aids in engineering $\mathrm{pH}$-activity profiles. Therefore, further research efforts are needed to find other factors that can contribute to the acid stability of proteins. Investigations have shown that it is possible to increase the thermostability, but not so with acidstability. Therefore, instead of increasing acid-stability of already existing thermostable enzymes, a better option is to improve the thermostability of acid-stable enzymes. Since $\alpha$-amylase from $B$. acidicola (Ba-amy) is stable in acidic conditions with moderate thermostability, an attempt has thus been made to improve thermostability (Parashar and Satyanarayana, 2016c). Several chimeras were constructed with the addition of amino acids at $\mathrm{N}$ and C-terminal ends of acid-stable Ba-amy from the $\alpha$-amylase of Geobacillus thermoleovorans (Gt-amy) (Figure 5). All chimeras were successfully expressed in active form in E. coli. Among all chimeras, one chimera displayed higher thermostability and specific activity as well as catalytic efficiency without change in its acid stability and $\mathrm{pH}$ optimum for activity (Parashar and Satyanarayana, 2016a). Increase in starch binding capacity of the chimeric $\alpha$-amylase was observed in comparison with that of the wild type. The adsorption of chimeric $\alpha$-amylase to raw starch suggests that the hydrolysis of raw starch can occur at high temperatures without energy-intensive gelatinization step, which brings down the energy consumption for starch saccharification. Furthermore, the end products of raw starch hydrolysis by the chimera suggested that the addition of residues did not alter the catalytic activity.

In another study, this chimeric $\alpha$-amylase was fused with acidstable glucoamylase of Aspergillus niger through a linker peptide for saccharifying starch in a single step (Figure 5) (Parashar and Satyanarayana, 2017b). The kinetic properties of the fused enzyme supported its suitability in raw starch saccharification in acidic conditions of native starch that liberates glucose besides maltodextrins as the major starch hydrolysis products. The fused chimeric enzyme can, therefore, be a practical option for the cost effective saccharification of raw starch. Engineering multidomain enzymes that are capable of catalyzing two or more reactions is a potential strategy to reduce enzyme costs in industrial processes because multiple catalytic properties in a single polypeptide simplify production and purification process (Fan et al., 2009; Ribeiro et al., 2011; Parashar and Satyanarayana, 2017b).

\section{CALCIUM BINDING REGION IN $\alpha$-AMYLASE}

Calcium is known to stimulate $\alpha$-amylases and has also been implicated in enhancing their thermostability (Savchenko et al., 2002). Acid-stable Ba-amy was found to be a calciumindependent. A few $\mathrm{Ca}^{2+}$-independent $\alpha$-amylases have also been reported earlier (Babu and Satyanarayana, 1993; Sajedi et al., 2005; Asoodeh et al., 2010), which were considered to be useful in industrial starch saccharification.

In general, most of the $\alpha$-amylases possess conserved calcium ion binding sites, which are positioned at the interface between domains $\mathrm{A}$ and $\mathrm{B}$, and play a major role in its stability and activity (Figure 6) (Boel et al., 1990; Linden et al., 2003). Bacillus $\alpha$-amylases have been reported to have three $\mathrm{Ca}^{2+}$ ions and one $\mathrm{Na}^{+}$ion and a metal triad bridge (calcium-sodiumcalcium) (Linden et al., 2003). This metal triad is important for maintaining the compact protein structure and provides thermal stability to the enzyme (Linden et al., 2003). Calcium ion helps in salting out of hydrophobic residues in the protein, resulting in the formation of a compact structure that enhances stability (Linden et al., 2003). Whenever calcium ions are detached, amylases lose their stability, while its restoration recovers the stability (Boel et al., 1990). Sequence analysis revealed that acidstable $\mathrm{Ba}$-amy comprises three calcium binding sites despite the fact that Ba-amy does not show any calcium-dependent activity. Since the calcium binding site is far away from the active site residues, it has been postulated that the role of calcium ions is in maintaining the structure rather than in catalysis. A second theory suggests that calcium is loosely bound, which is replaced by other metal ions such as $\mathrm{Na}^{+}$. These theories get support from the investigations on other calcium-independent enzymes (Nonaka et al., 2003).

\section{COMMERCIAL APPLICATION OF ACIDSTABLE AMYLASES}

Extremophiles are potent sources of extremozymes, which display a high stability under extreme bioprocess conditions (Elleuche et al., 2014). Thus biocatalysts from extremophiles have been shown to be useful in industrial bioprocesses. Only a few extremozymes, however, found their way to the market (e.g., thermostable DNA polymerases from Thermus aquaticus and Pyrococcus furiosus and others). There is a

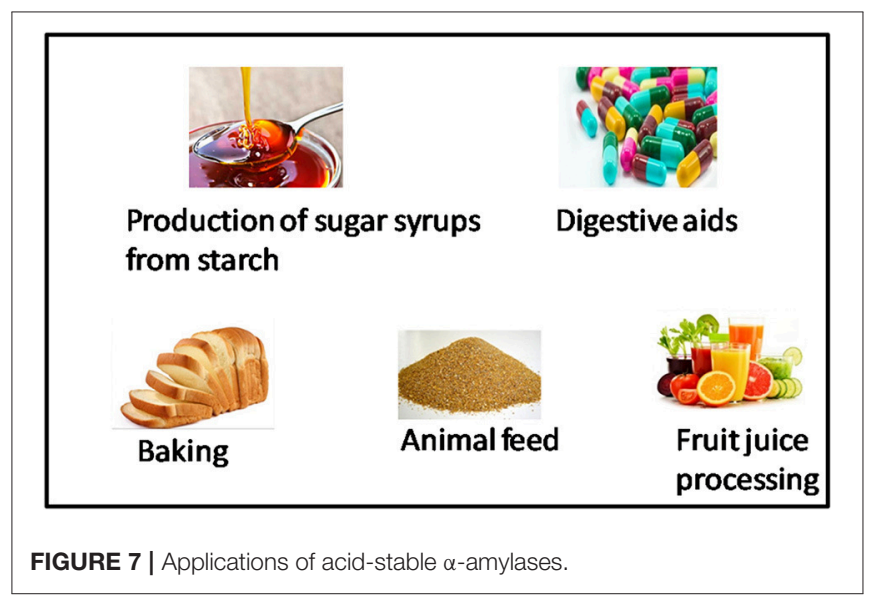


tremendous potential for acidstable enzymes from acidophiles to revolutionize existing industrial processes and to make many novel applications possible (Figure 7) (Mehta and Satyanarayana, 2016; Sharma et al., 2016). Moreover, acidstable $\alpha$-amylases reduce the cost and time required for multistep maltooligosachharide production from raw starches, which can be used as antistaling agents in baking industry (Parashar and Satyanarayana, 2016c). Other acid-stable enzymes have potential biotechnological and industrial applications (Figure 7).

\section{CONCLUSIONS}

$\alpha$-Amylases produced by acidophilic microorganisms find applications in industrial processes such as starch saccharification and hydrolysis of polysaccharides in plant biomass in bioethanol production. The analysis of structure of these proteins suggests that acid-stable biocatalysts differ in surface charge, amino acid composition, salt bridges, and hydrophobicity. There

\section{REFERENCES}

Asoodeh, A., Chamani, J., and Lagzian, M. (2010). A novel thermostable, acidophilic $\alpha$-amylase from a new thermophilic "Bacillus sp. Ferdowsicous" isolated from Ferdows hot mineral spring in Iran: purification and biochemical characterization. Int. J. Biol. Macromol. 46, 289-297. doi: 10.1016/j.ijbiomac.2010.01.013

Asoodeh, A., Emtenani, S., Emtenani, S., Jalal, R., and Housaindokht, M. R. (2014). Molecular cloning and biochemical characterization of a thermoacidophilic, organic-solvent tolerant $\alpha$-amylase from a Bacillus strain in Escherichia coli. J. Molecular Cat. B: Enzymatic. 99, 114-120. doi: 10.1016/j.molcatb.2013.10.025

Auernik, K. S., Cooper, C. R., and Kelly, R. M. (2008). Life in hot acid: pathway analyses in extremely thermoacidophilic archaea. Curr. Opin. Biotechnol. 19, 445-453. doi: 10.1016/j.copbio.2008.08.001

Babu, K. R., and Satyanarayana, T. (1993). Extracellular calcium-inhibited alphaamylase of Bacillus coagulans B 49. Enz. Microb. Technol. 15, 1066-1069. doi: 10.1016/0141-0229(93)90056-8

Babu, K. R., and Satyanarayana, T. (1995). $\alpha$-Amylase production by thermophilic Bacillus coagulans in solid state fermentation. Process Biochem. 30, 305-309. doi: 10.1016/0032-9592(95)87038-5

Bai, Y., Huang, H., Meng, K., Shi, P., Yang, P., Luo, H., et al. (2012). Identification of an acidic $\alpha$-amylase from Alicyclobacillus sp. A4 and assessment of its application in the starch industry. Food Chem. 131, 1473-1478. doi: 10.1016/j.foodchem.2011.10.036

Baker-Austin, C., and Dopson, M. (2007). Life in acid: pH homeostasis in acidophiles. Trends Microbiol. 15, 165-171. doi: 10.1016/j.tim.2007.02.005

Bhattacharyya, S., Chakrabarty, B. K., Das, A., Jundu, P., and Banerjee, P. C. (1990). Acidiphilium symbioticum sp. nov., an acidophilic heterotrophic bacterium from Thiobacillus ferrooxidans cultures isolated from Indian mines. Can. J. Microbiol. 37, 78-85. doi: 10.1139/m91-012

Boel, E., Brady, L., Brzozowski, A. M., Derewenda, Z., Dodson, G. G., Jensen, V. J., et al. (1990). Calcium binding in $\alpha$-amylases: an x-ray diffraction study at 2.1 Å. resolution of two enzymes from Aspergillus. Biochemistry 29, 6244-6249. doi: 10.1021/bi00478a019

Brock, T. D., Brock, K. M., Belly, R. T., and Weiss, R. L. (1972). Sulfolobus: a new genus of sulphur-oxidizing bacteria living at low $\mathrm{pH}$ and high temperature. Arch. Mikrobiol. 84, 54-68. doi: 10.1007/BF00408082

Brown, S. H., Costantino, H. R., and Kelly, R. M. (1990). Characterization of amylolytic enzyme activities associated with the hyperthermophilic archaebacterium Pyrococcus furiosus. Appl. Environ. Microbiol. 56, 1985-1991.

Chen, L., Brügger, K., Skovgaard, M., Redder, P., She, Q., Torarinsson, E., et al. (2005). The genome of Sulfolobus acidocaldarius, a are very few successful attempts in improving acid-stability of enzymes through protein engineering. These studies lack adequate rational concept, thus, difficult to apply for other proteins. Extensive as well as intensive efforts are, therefore, called for attaining high titres of acid-stable $\alpha$-amylases and to understand the mechanisms which make them functional at low $\mathrm{pH}$ for ameliorating the existing enzymes for novel industrial applications.

\section{AUTHOR CONTRIBUTIONS}

All authors listed have made a substantial, direct and intellectual contribution to the work, and approved it for publication.

\section{ACKNOWLEDGMENTS}

One of us (TS) is grateful to the University Grants Commission, Govt. of India, New Delhi for granting BSR Faculty Fellowship while writing this review.

model organism of the Crenarchaeota. J. Bacteriol. 187, 4992-4999. doi: 10.1128/JB.187.14.4992-4999.2005

Clark, D. A., and Norris, P. R. (1996). Acidimicrobium ferrooxidans gen. nov., sp. nov.: mixed-culture ferrous iron oxidation with Sulfobacillus species. Microbiology 142, 785-790. doi: 10.1099/00221287-142-4-785

Crabb, W. D., and Mitchinson, C. (1997). Enzymes involved in the processing of starch to sugars. Trends Biotechnol. 15, 349-352. doi: 10.1016/S0167-7799(97)01082-2

Cregg, J. M., Tolstorukov, I., Kusari, A., Sunga, J., Madden, K., and Chappell, T. (2009). Expression in the yeast Pichia pastoris. Methods Enzymol. 463, 169-189. doi: 10.1016/S0076-6879(09)63013-5

Darland, G., Brock, T. D., Samsonoff, W., and Conti, S. F. (1970). A thermophilic, acidophilic mycoplasma isolated from a coal refuse pile. Science 170, 1416-1418. doi: 10.1126/science.170.3965.1416

Demirjian, D. C., Morís-Varas, F., and Cassidy, C. S. (2001). Enzymes from extremophiles. Curr. Opin. Chem. Biol. 5, 144-151. doi: 10.1016/S1367-5931(00)00183-6

Dong, G., Vieille, C., Savchenko, A., and Zeikus, J. G. (1997). Cloning, sequencing, and expression of the gene encoding extracellular alpha-amylase from Pyrococcus furiosus and biochemical characterization of the recombinant enzyme. Appl. Environ. Microbiol. 63, 3569-3576.

Eichler, J. (2001). Biotechnological uses of archaeal extremozymes. Biotechnol. Advances. 19, 261-278. doi: 10.1016/S0734-9750(01)00061-1

Elleuche, S., Schröder, C., Sahm, K., and Antranikian, G. (2014). Extremozymesbiocatalysts with unique properties from extremophilic microorganisms. Curr. Opin. Biotechnol. 29, 116-123. doi: 10.1016/j.copbio.2014.04.003

Fan, Z., Wagschal, K., Lee, C. C., Kong, Q., Shen, K. A., Maiti, I. B., et al. (2009). The construction and characterization of two xylan-degrading chimeric enzymes. Biotechnol. Bioeng. 102, 684-692. doi: 10.1002/bit.22112

Ferrer, M., Golyshina, O., Beloqui, A., and Golyshin, P. N. (2007). Mining enzymes from extreme environments. Curr. Opin. Microbiol. 10, 207-214. doi: 10.1016/j.mib.2007.05.004

Fuchs, T., Huber,. H., Teiner,. K., Burggraf,. S., and Stetter,. K. O. (1996). Metallosphaera prunae, sp. nov., a novel metal-mobilizing, thermoacidophilic archaeum, isolated from a uranium mine in Germany. Syst. Appl. Microbiol. 18, 560-566. doi: 10.1016/S0723-2020(11)80416-9

Gangadharan, D., Sivaramakrishnan, S., Nampoothiri, K. M., and Pandey, A. (2006). Solid culturing of Bacillus amyloliquefaciens for alpha amylase production. Food Technol. Biotechnol. 44, 269-274.

Golovacheva, R. S., Golyshina, O. V., Karavaiko, G. I., Dorofeev, A. G., and Cheruykh, N. A. (1992). The new iron-oxidizing bacterium Leptospirillum thermoferrooxidans sp. nov. Microbiology 61, 744-750. 
Golovacheva, R. S., and Karavaiko, G. I. (1978). A new genus of thermophilic spore-forming bacteria, Sulfobacillus. Microbiology 47, 658-665.

González-Toril, E., Llobet-Brossa, E., Casamayor, E. O., Amann, R., and Amils, R. (2003). Microbial ecology of an extreme acidic environment, the Tinto River. App. Environ. Microbiol. 69, 4853-4865. doi: 10.1128/AEM.69.8.4853-4865.2003

Grogan, D., Palm, P., and Zillig, W. (1990). Isolate B12 which harbors a viruslike element represents a new species of the archaebacterial genus Sulfolobus, Sulfolobus shibatae new species. Arch. Microbiol. 154, 594-599. doi: 10.1007/BF00248842

Grzybowska, B., Szweda, P., and Synowiecki, J. (2004). Cloning of the thermostable $\alpha$-amylase gene from Pyrococcus woesei in Escherichia coli. Mol. Biotechnol. 26, 101-109. doi: 10.1385/MB:26:2:101

Harrison, A. P. (1981). Acidiphilium cryptum gen. nov., sp. nov., heterotrophic bacterium from acidic mineral environments. Int. J. Syst. Bacteriol. 31, 327-332. doi: 10.1099/00207713-31-3-327

Hedrich, S., and Johnson, D. B. (2013). Acidithiobacillus ferridurans sp. nov., an acidophilic iron-, sulfur-and hydrogen-metabolizing chemolithotrophic gamma proteobacterium. Int. J. Syst. Evol. Microbiol. 63, 4018-4025. doi: 10.1099/ijs.0.049759-0

Hough, D. W., and Danson, M. J. (1999). Extremozymes. Curr. Opin Chem. Biol. 3, 39-46. doi: 10.1016/S1367-5931(99)80008-8

Huang, Y., Krauss, G., Cottaz, S., Driguez, H., and Lipps, G. (2005). A highly acidstable and thermostable endo- -glucanase from the thermoacidophilic archaeon Sulfolobus solfataricus. Biochem. J. 385, 581-588. doi: 10.1042/BJ20041388

Huber, G., Spinnler, C., Gambacorta, A., and Stetter, K. O. (1989). Metallosphaera sedula gen. and sp.nov. represents a new genus of aerobic, metalmobilizing, thermoacidophilic archaebacteria. Syst. Appl. Microbiol. 12, 38-47. doi: 10.1016/S0723-2020(89)80038-4

Huber, G., and Stetter, K. O. (1991). Sulfolobus metallicus, sp. nov., a novel strictly chemolithoautotrophic thermophilic archaeal species of metal mobilizers. Syst. Appl. Microbiol. 14, 372-378. doi: 10.1016/S0723-2020(11)80312-7

Itoh, T., Yoshikawa, N., and Takashina, T. (2007). Thermogymnomonas acidicola gen. nov., sp. nov., a novel thermoacidophilic, cell wall-less archaeon in the order Thermoplasmatales, isolated from a solfataric soil in Hakone, Japan. Int. J. Syst. Evol. Microbiol. 57, 2557-2561. doi: 10.1099/ijs.0.65203-0

Johnson, D. B. (1998). Biodiversity and ecology of acidophilic microorganisms. FEMS Microbiol. Ecol. 27, 307-317. doi: 10.1111/j.1574-6941.1998.tb00547.x

Joshi, S., and Satyanarayana, T. (2015). In vitro engineering of microbial enzymes with multifarious applications: prospects and perspectives. Biores. Technol. 176, 273-283. doi: 10.1016/j.biortech.2014.10.151

Joyet, P., Guerineau, M., and Heslot, H. (1984). Cloning of a thermostable $\alpha$-amylase gene from Bacillus licheniformis and its expression in Escherichia coli and Bacillus subtilis. FEMS Microbiol. Lett. 21, 353-358. doi: 10.1016/0378-1097(84)90097-1

Kanno, M. (1986). $\alpha$-Amylase production by Bacillus acidocaldarius, $B$. stearothermophilus and their D-cycloserine resistant mutants. Agric. Biol. Chem. 50, 2633-2635. doi: 10.1271/bbb1961.50.2633

Karavaiko, G. I., Golyshina, O. V., Troitskii, A. V., Valiehoroman, K. M., Golovacheva, R. S., and Pivovarova, T. A. (1994). Sulfurococcus yellowstonii sp. nov., a new species of iron oxidizing and sulphur oxidizing thermoacidophilic archaebacteria. Microbiology 63, 379-387.

Koch, R., Spreinat, A., Lemke, K., and Antranikian, G. (1991). Purification and properties of a hyperthermoactive $\alpha$-amylase from the archaeobacterium Pyrococcus woesei. Arch. Microbiol. 155, 572-578. doi: 10.1007/BF002 45352

Kumar, P., and Satyanarayana, T. (2007). Optimization of culture variables for improving glucoamylase production by alginate-entrapped Thermomucor indicae-seudaticae using statistical methods. Biores. Technol. 98, 1252-1259. doi: 10.1016/j.biortech.2006.05.019

Kurosawa, N., Itoh, Y. H., Iwai, T., Sugai, A., Uda, I., Kimura, N., et al. (1998). Sulfurisphaera ohwakuensis gen. nov., sp. nov., a novel extremely thermophilic acidophile of the order Sulfolobales. Int. J. Syst. Bacteriol. 48, 451-456. doi: 10.1099/00207713-48-2-451

Laderman, K. A., Davis, B. R., Krutzsch, H. C., Lewis, M. S., Griko, Y. V., Privalov, P. L., et al. (1993). The purification and characterization of an extremely thermostable alpha-amylase from the hyperthermophilic archaebacterium Pyrococcus furiosus. J. Biol. Chemistry 268, 24394-24301.
Linden, A., Mayans, O., Meyer-Klaucke, W., Antranikian, G., and Wilmanns, M. (2003). Differential regulation of a hyperthermophilic $\alpha$-amylase with a novel (Ca, $\mathrm{Zn})$ two-metal center by zinc. J. Biol. Chem. 278, 9875-9884. doi: 10.1074/jbc.M2113 39200

Liu, Y. H., Hu, B., Xu, Y. J., Bo, J. X., Fan, S., Wang, J. L., et al. (2012). Improvement of the acid stability of Bacillus licheniformis $\alpha$-amylase by error-prone PCR. J. App. Microbiol. 113, 541-549. doi: 10.1111/j.1365-2672.2012.05359.x

Liu, Y. H., Lu, F. P., Li, Y., Wang, J. L., and Gao, C. (2008a). Acid stabilization of Bacillus licheniformis alpha-amylase through introduction of mutations. App. Microbiol. Biotechnol. 80, 795-803. doi: 10.1007/s00253-008-1580-5

Liu, Y. H., Lu, F. P., Li, Y., Yin, X. B., Wang, Y., and Gao, C. (2008b). Characterization of mutagenised acid-resistant alpha-amylase expressed in Bacillus subtilis WB600. Appl. Microbiol Biotechnol. 78, 85-94. doi: $10.1007 / \mathrm{s} 00253-007-1287-\mathrm{z}$

Lobos, J. H., Chisholm, T. E., Bopp, L. H., and Holmes, D. S. (1986). Acidiphilium organovorum sp. nov., an acidophilic heterotroph isolated from a Thiobacillus ferrooxidans culture. Int. J. Syst. Bacteriol. 36, 139-144. doi: 10.1099/00207713-36-2-139

Matsubara, H., Goto, K., Matsumura, T., Mochida, K., Iwaki, M., Niwa, M., et al. (2002). Alicyclobacillus acidiphilus sp. nov., a novel thermo-acidophilic, omegaalicyclic fatty acid-containing bacterium isolated from acidic beverages. Int. J. Syst. Evol. Microbiol. 52, 1681-1685. doi: 10.1099/00207713-52-5-1681

Matzke, J., Schwermann, B., and Bakker, E. P. (1997). Acidostable and acidophilic proteins: the example of the $\alpha$-amylase from Alicyclobacillus acidocaldarius. Comparative Biochem. Physiol. Part A Physiol. 118, 475-479.

Mavromatis, K., Sikorski, J., Lapidus, A., Del Rio, T. G., Copeland, A., Tice, H., et al. (2010). Complete genome sequence of Alicyclobacillus acidocaldarius type strain (104-IA T). Standards Genomic Sci. 2, 9-21. doi: 10.4056/sigs.591104

Mehta, D., and Satyanarayana, T. (2013). Biochemical and molecular characterization of recombinant acidic and thermostable rawstarch hydrolysing $\alpha$-amylase from an extreme thermophile Geobacillus thermoleovorans. J. Mol. Catal. B Enz. 85, 229-238. doi: 10.1016/j.molcatb.2012.08.017

Mehta, D., and Satyanarayana, T. (2014). Domain C of thermostable $\alpha$-amylase of Geobacillus thermoleovorans mediates raw starch adsorption. App. Microbiol. Biotechnol. 98, 4503-4519. doi: 10.1007/s00253-013-5459-8

Mehta, D., and Satyanarayana, T. (2016). Bacterial and archaeal $\alpha$-amylases: diversity and amelioration of the desirable characteristics for industrial applications. Front. Microbiol. 7:1129. doi: 10.3389/fmicb.2016.01129

Murakami, S., Nishimoto, H., Toyama, Y., Shimamoto, E., Takenaka, S., Kaulpiboon, J., et al. (2007). Purification and characterization of two alkaline, thermotolerant $\alpha$-amylases from Bacillus halodurans 38C-2-1 and expression of the cloned gene in Escherichia coli. Biosci. Biotechnol. Biochem. 71, 2393-2401. doi: 10.1271/bbb.60666

Nielsen, J. E., Beier, L., Otzen, D., Borchert, T. V., Frantzen, H. B., Andersen, K. V., et al. (1999). Electrostatics in the active site of an $\alpha$-amylase. FEBS J. 264, 816-824. doi: 10.1046/j.1432-1327.1999.00664.x

Nielsen, J. E., and Borchert, T. V. (2000). Protein engineering of bacterial $\alpha$-amylases. Biochim. Biophys. Acta 1543, 253-274. doi: 10.1016/S0167-4838(00)00240-5

Nonaka, T., Fujihashi, M., Kita, A., Hagihara, H., Ozaki, K., Ito, S., et al. (2003). Crystal structure of calcium-free $\alpha$-amylase from Bacillus sp. strain KSM-K38 (AmyK38) and its sodium ion binding sites. J. Biol.Chem. 278, 24818-24824. doi: $10.1074 /$ jbc.M212763200

Norris, P. R., Clark, D. A., Owen, J. P., and Waterhouse, S. (1996). Characteristics of Sulfobacillus acidophilus sp. nov. and other moderately thermophilic mineral-sulfide-oxidizing bacteria. Microbiology 142, 775-783. doi: $10.1099 / 00221287-142-4-775$

Orr, R. V., Shewfelt, R. L., Huang, C. J., Tefera, S., and Beuchat, L. R. (2000). Detection of guaiacol produced by Alicyclobacillus acidoterrestris in apple juice by sensory and chromatographic analyses, and comparison with spore and vegetative cell populations. J. Food Protec. 63, 1517-1522. doi: 10.4315/0362-028X-63.11.1517

Parashar, D., and Satyanarayana, T. (2016a). Production of $\mathrm{Ca}^{2+}$-independent and acidstable Recombinant $\alpha$-amylase of Bacillus acidicola extracellularly and its applicability in generating maltooligosaccharides. Mol. Biotechnol. 58, 707-717. doi: $10.1007 / \mathrm{s} 12033-016-9970-\mathrm{x}$ 
Parashar, D., and Satyanarayana, T. (2016b). Enhancing the production of recombinant acidic $\alpha$-amylase and phytase in Pichia pastoris under dual promoters [constitutive (GAP) and inducible (AOX)] in mixed fed batch high cell density cultivation. Process Biochem. 51, 1315-1322. doi: 10.1016/j.procbio.2016.07.027

Parashar, D., and Satyanarayana, T. (2016c). A chimeric $\alpha$-amylase engineered from Bacillus acidicola and Geobacillus thermoleovorans with improved thermostability and catalytic efficiency. J. Ind. Microbiol. Biotechnol. 43, 473-484. doi: 10.1007/s10295-015-1721-7

Parashar, D., and Satyanarayana, T. (2017a). Production of chimeric acidic $\alpha$-amylase by the recombinant Pichia pastoris and its applications. Front. Microbiol. 8:493. doi: 10.3389/fmicb.2017.00493

Parashar, D., and Satyanarayana, T. (2017b). Engineering a chimeric acid-stable $\alpha$-amylase-glucoamylase (Amy-Glu) for one step starch saccharification. Int. J. Biol. Macromol. 99, 274-281. doi: 10.1016/j.ijbiomac.2017.02.083

Pedersen, H., and Nielsen, J. (2000). The influence of nitrogen sources on the $\alpha$-amylase productivity of Aspergillus oryzae in continuous cultures. App. Microbiol. Biotechnol. 53, 278-281. doi: 10.1007/s002530050021

Peng, S., Chu, Z., Lu, J., Li, D., Wang, Y., Yang, S., et al. (2016). Co-expression of chaperones from $P$. furiosus enhanced the soluble expression of the recombinant hyperthermophilic $\alpha$-amylase in E. coli. Cell Stress Chaperones 21, 477-484. doi: 10.1007/s12192-016-0675-7

Priyadharshini, R., Manoharan, S., Hemalatha, D., and Gunasekaran, P. (2010). Repeated random mutagenesis of $\alpha$-amylase from Bacillus licheniformis for improved $\mathrm{pH}$ performance. J. Microbiol. Biotechnol. 20, 1696-1701. doi: $10.4014 / \mathrm{jmb} .1008 .08013$

Prokofeva, M. I., Miroshnichenko, M. L., Kostrikina, N. A., Chernyh, N. A., Kuznetsov, B. B., Tourova, T. P., et al. (2000). Acidilobus aceticus gen. nov., sp. nov., a novel anaerobic thermoacidophilic archaeon from continental hot vents in Kamchatka. Int. J. Syst. Evol. Microbiol. 50, 2001-2008. doi: 10.1099/00207713-50-6-2001

Raddadi, N., Cherif, A., Daffonchio, D., Neifar, M., and Fava, F. (2015). Biotechnological applications of extremophiles, extremozymes and extremolytes. Appl. Microbial. Biotechnol. 99, 7907-7913. doi: 10.1007/s00253-015-6874-9

Ranjan, B., and Satyanarayana, T. (2016). Recombinant HAP phytase of the thermophilic mold Sporotrichum thermophile: expression of the codonoptimized phytase gene in Pichia pastoris and applications. Mol. Biotechnol. 58, 137-147. doi: 10.1007/s12033-015-9909-7

Reed, C. J., Lewis, H., Trejo, E., Winston, V., and Evilia, C. (2013). Protein adaptations in archaeal extremophiles. Archaea 13, 1-14. doi: $10.1155 / 2013 / 373275$

Ren-Long, J., Wu, J., Chaw, S. M., Tsai, C. W., and Tsen, S. D. (1999). A novel species of thermoacidophilic archaeon, Sulfolobus yangmingensis sp. nov. Int. J. Syst. Bacteriol. 49, 1809-1816. doi: 10.1099/00207713-49-4-1809

Ribeiro, L. F., Furtado, G. P., Lourenzoni, M. R., Costa-Filho, A. J., Santos, C. R., Nogueira, S. C., et al. (2011). Engineering bifunctional laccase-xylanase chimeras for improved catalytic performance. J. Biol. Chem. 286, 43026-43038. doi: 10.1074/jbc.M111.253419

Sajedi, R. H., Naderi-Manesh, H., Khajeh, K., Ahmadvand, R., Ranjbar, B., Asoodeh, A., et al. (2005). A Ca-independent $\alpha$-amylase that is active and stable at low pH from the Bacillus sp. K1R-8104. Enz. Microb. Technol. 36, 666-671. doi: 10.1016/j.enzmictec.2004.11.003

Savchenko, A., Vieille, C., Kang, S., and Zeikus, J. G. (2002). Pyrococcus furiosus $\alpha$-amylase is stabilized by calcium and zinc. Biochemistry 41, 6193-6201. doi: 10.1021/bi012106s

Schäfer, K., Magnusson, U., Scheffel, F., Schiefner, A., Sandgren, M. O., Diederichs, K., et al. (2004). X-ray structures of the maltose-maltodextrin-binding protein of the thermoacidophilic bacterium Alicyclobacillus acidocaldarius provide insight into acid stability of proteins. J. Mol. Biol. 335, 261-274. doi: 10.1016/j.jmb.2003.10.042

Schleper, C., Puehler, G., Holz, I., Gambacorta, A., Janekovic, D., and Santarius, U. (1995). Picrophilus gen. nov., fam. Nov. a novel aerobic, heterotrophic, thermoacidophilic genus and family comprising archaea capable of growth around $\mathrm{pH}$ 0. J. Bacteriol. 177, 7050-7059.

Schwermann, B., Pfau, K., Liliensiek, B., Schleyer, M., Fischer, T., and Bakker, E. P. (1994). Purification, properties and structural aspects of a thermoacidophilic $\alpha$-amylase from Alicyclobacillus acidocaldarius ATCC 27009. FEBS J. 226, 981-991.

Segerer, A., Langworthy, T. A., and Stetter, K. O. (1988). Thermoplasma acidophilum and Thermoplasma volcanium sp. nov. from solfatara fields. Syst. Appl. Microbiol. 10, 161-171.

Segerer, A., Neuner, A., Kristjansson, J. K., and Stetter, K. O. (1986). Acidianus infernus gen. nov., sp. nov., and Acidianus brierleyi comb. nov.: facultatively aerobic, extremely acidophilic thermophilic sulfurmetabolizing archaebacteria. Int. J. Syst. Evol. Microbiol. 36, 559-564. doi: 10.1099/00207713-36-4-559

Sharma, A., Kawarabayasi, Y., and Satyanarayana, T. (2012). Acidophilic bacteria and archaea: acid-stable biocatalysts and their potential applications. Extremophiles 16, 1-19. doi: 10.1007/s00792-011-0402-3

Sharma, A., Parashar, D., and Satyanarayana, T. (2016). "Acidophilic Microbes: Biology and Applications," in Biotechnology of Extremophiles, ed P. H. Rampelotto (Cham: Springer International Publishing), 215-241.

Sharma, A., and Satyanarayana, T. (2010). High maltose-forming, $\mathrm{Ca}^{+}{ }^{-}$-independent and acid-stable $\alpha$-amylase from a novel acidophilic bacterium, Bacillus acidicola. Biotechnol. Lett. 32, 1503-1507. doi: 10.1007/s10529-010-0322-9

Sharma, A., and Satyanarayana, T. (2011). Optimization of medium components and cultural variables for enhanced production of acidic high maltose-forming and $\mathrm{Ca}_{2}{ }^{+}$-independent $\alpha$-amylase by Bacillus acidicola. J. Biosci. Bioeng. 111, 550-553. doi: 10.1016/j.jbiosc.2011.01.004

Sharma, A., and Satyanarayana, T. (2012a). Cloning and expression of acidstable, high maltose-forming, $\mathrm{Ca}_{2}{ }^{+}$-independent $\alpha$-amylase from an acidophile Bacillus acidicola and its applicability in starch hydrolysis. Extremophiles 16, 515-522. doi: 10.1007/s00792-012-0451-2

Sharma, A., and Satyanarayana, T. (2012b). Production of acid-stable and high maltose-forming $\alpha$-amylase of Bacillus acidicola by solid-state fermentation and immobilized cells and its applicability in baking. Appl. Biochem. Biotechnol. 168, 1025-1034. doi: 10.1007/s12010-012-9838-x

Sharma, A., and Satyanarayana, T. (2013a). Microbial acid-stable $\alpha$-amylases: characteristics, genetic engineering and applications. Process Biochem. 48, 201-211. doi: 10.1016/j.procbio.2012.12.018

Sharma, A., and Satyanarayana, T. (2013b). Structural and biochemical features of acidic $\alpha$-amylase of Bacillus acidicola. Int. J. Biol. Macromol. 61, 416-423. doi: 10.1016/j.ijbiomac.2013.08.003

Shaw, A., Bott, R., and Day, A. G. (1999). Protein engineering of $\alpha$ amylase for low pH performance. Curr. Opin. Biotechnol. 10, 349-352. doi: 10.1016/S0958-1669(99)80063-9

Shima, S., and Suzuki, K. I. (1993). Hydrogenobacter acidophilus sp. nov., a thermoacidophilic, aerobic, hydrogen-oxidizing bacterium requiring elemental sulfur for growth. Int. J. Syst. Evol. Microbiol. 43, 703-708. doi: 10.1099/00207713-43-4-703

Shirokizawa, O., Akiba, T., and Horikoshi, K. (1990). Nucleotide sequence of the G6-amylase gene from alkalophilic Bacillus sp. H-167. FEMS Microbiol. Lett. 70, 131-135. doi: 10.1111/j.1574-6968.1990.tb13965.x

Spohner, S. C., Müller, H., Quitmann, H., and Czermak, P. (2015). Expression of enzymes for the usage in food and feed industry with Pichia pastoris. J. Biotechnol. 202, 118-134. doi: 10.1016/j.jbiotec.2015.01.027

Uma Maheswar Rao, J. L., and Satyanarayana, T. (2003). Statistical optimization of a high maltose-forming, hyperthermostable and $\mathrm{Ca}_{2}{ }^{+}$-independent alphaamylase production by an extreme thermophile Geobacillus thermoleovorans using response surface methodology. J. App. Microbiol. 95, 712-718. doi: $10.1046 / j .1365-2672.2003 .02036 . x$

Verma, D., and Satyanarayana, T. (2012). Molecular approaches for ameliorating microbial xylanases. Biores. Technol. 117, 360-367. doi: 10.1016/j.biortech.2012.04.034

Wang, L., Zhou, Q., Chen, H., Chu, Z., Lu, J., Zhang, Y., et al. (2007). Efficient solubilization, purification of recombinant extracellular $\alpha$-amylase from Pyrococcus furiosus expressed as inclusion bodies in Escherichia coli. J. Ind. Microbiol. Biotechnol. 34, 187-192. doi: 10.1007/s10295-006-0 185-1

Wang, P., Wang, P., Tian, J., Yu, X., Chang, M., Chu, X., et al. (2016). A new strategy to express the extracellular $\alpha$-amylase from Pyrococcus furiosus in Bacillus amyloliquefaciens. Sci. Rep. 6, 222-229. doi: 10.1038/srep22229 
Widersten, M. (2014). Protein engineering for development of new hydrolytic biocatalysts. Curr. Opin. Chem. Biol. 21, 42-47. doi: 10.1016/j.cbpa.2014.0 3.015

Wind, R. D., Uitdehaag, J. C., Buitelaar, R. M., Dijkstra, B. W., and Dijkhuizen, L. (1998). Engineering of cyclodextrin product specificity and $\mathrm{pH}$ optima of the thermostable cyclodextrin glycosyltransferase from Thermoanaerobacterium thermosulfurigenes EM1. J. Biological. Chem. 273, 5771-5779. doi: 10.1074/jbc.273.10.5771

Xiang, X., Dong, X., and Huang, L. (2003). Sulfolobus tengchongensis sp. nov., a novel thermoacidophilic archaeaon isolated from a hot spring in Tengchong, China. Extremophiles 7, 493-498. doi: 10.1007/s00792-003-0355-2

Yang, H., Liu, L., Shin, H. D., Chen, R. R., Li, J., Du, G., et al. (2013). Structure-based engineering of histidine residues in the catalytic domain of $\alpha$-amylase from Bacillus subtilis for improved protein stability and catalytic efficiency under acidic conditions. J. Biotechnol. 164, 59-66. doi: 10.1016/j.jbiotec.2012.12.007

Zhang, R. Y., Xia, J. L., Peng, J. H., Zhang, Q., Zhang, C. G., Nie, Z. Y., et al. (2010). A new strain Leptospirillum ferriphilum YTW315 for bioleaching of metal sulfides ores. Trans. Nonferrous Metals Soc. China 20, 135-141. doi: 10.1016/S1003-6326(09)60110-2

Zhu, H., Reynolds, L. B., and Menassa, R. (2017). A hyper-thermostable $\alpha$-amylase from Pyrococcus furiosus accumulates in Nicotiana tabacum as functional aggregates. BMC Biotechnol. 17:53. doi: 10.1186/s12896-017-0372-3

Conflict of Interest Statement: The authors declare that the research was conducted in the absence of any commercial or financial relationships that could be construed as a potential conflict of interest.

Copyright (c) 2018 Parashar and Satyanarayana. This is an open-access article distributed under the terms of the Creative Commons Attribution License (CC BY). The use, distribution or reproduction in other forums is permitted, provided the original author(s) and the copyright owner(s) are credited and that the original publication in this journal is cited, in accordance with accepted academic practice. No use, distribution or reproduction is permitted which does not comply with these terms. 